\title{
W labiryntach czasu i wieczności. O Lśnieniu Stanleya Kubricka
}

\begin{abstract}
Kościelski Kamil, W labiryntach czasu i wieczności. O "Lśnieniu” Stanleya Kubricka [In the labyrinth of time and eternity: on Stanley Kubrick's The Shining]. "Przestrzenie Teorii" 22. Poznań 2014, Adam Mickiewicz University Press, pp. 171-187. ISBN 978-83-232-2827-1. ISSN 1644-6763.
\end{abstract}

In the interview which appeared after the premiere of The Shining, Kubrick said that the fantastic qualities of reality in his movies are "treated in a very [...] ordinary way". He indicated that uncanny events are also depicted in this way in Jorge Luis Borges' writings. The comparison made by Kubrick should not be disregarded since the labyrinth motif, which does not appear in Stephen King's book that has been adapted for the screen, is an important theme in Borges' works as well as in The Shining. The Garden of Forking Paths, which was also written by this Argentinian writer, not only explores the above-mentioned motif, but also describes the conception of time which can be found in The Shining and in the last scene of Kubrick's 2001: A Space Odyssey. Borges' literary works might be helpful in comprehending Kubrick's notion of the fourth dimension. The coexistence of different times in The Shining, in turn, refers to the theological idea of eternity. This conception corresponds to the main character's nature - especially his desires, aspirations and anxieties. The established perspective provides an opportunity to exemplify what Kubrick meant by showing the fantastic qualities of reality "in a simple, non-baroque style".

Stanley Kubrick należał do grona twórców, którzy starali się budować znaczenie filmu na wielu płaszczyznach, wykorzystując przy tym przeróżne konteksty kulturowe. Poszczególne obrazy reżysera stanowią zresztą świadectwo jego niewątpliwej erudycji. Mnożyć można przykłady odniesień literackich, malarskich i muzycznych, jakie odnajdziemy w jego filmografii. W Barrym Lyndonie zauważono liczne odwołania do osiemnastowiecznego malarstwa, a w postaci Lady Lyndon słusznie doszukiwano się podobieństwa do Miss Robinson, sportretowanej przez Thomasa Gainsborough $^{1}$. Znane jest również, pojawiające się w Dr Strangelove, nawiązanie do Podróży Guliwera Jonathana Swifta ${ }^{2}$. U angielskiego pisarza Laputa jest określeniem latającej wyspy zamieszkanej przez naukowców, a u Kubricka z kolei - nazwą sowieckiej bazy rakietowej, która

1 „[...] Tym, co mogłoby być zadowalającym opisem Marisy Berenson jako Lady Lyndon, jest interpretacja, którą daje Richard Hamann w odniesieniu do portretu Miss Robinson Thomasa Gainsborough (1727-1788)". P.W. Jansen, Kommentierte Filmografie, [w:] Stanley Kubrick, hrsg. von P.W. Jansen und W. Schütte, München-Wien 1984, s. 162.

2 S. Frosali, Eklektyzm o niezwyktej jednorodności, tłum. U. Franczyk, [w:] Stanley Kubrick w opinii krytyki zagranicznej, red. D. Zielińska, Warszawa 1989, s. 81. 
stanowi główny cel dla amerykańskiej armii w przypadku wybuchu wojny nuklearnej. W Oczach szeroko zamkniętych żonę Billa uznaje się za filmowe odzwierciedlenie tytułowej postaci z powieści Lewisa Carrolla Alicja po drugiej stronie lustra, co zresztą zostaje podkreślone przez zbieżność imion obu bohaterek ${ }^{3}$.

Powyższe przykłady bardzo dobrze obrazują pewien element charakterystycznej dla Kubricka strategii artystycznej. Reżyser, posługując się stylizacją, a raczej przetworzeniem, nadaje swym postaciom i całej historii pewien dodatkowy kontekst. Pogłębia odbiór kręconych przez siebie filmów o kolejną warstwę, czasami pozornie odmienną od dosłownego szkieletu fabularnego. Niemniej jednak w wypadku Kubricka wszelkie powiązania $\mathrm{z}$ innymi dziedzinami sztuki oraz zawarte $\mathrm{w}$ filmie poglądy twórcy nigdy nie zostają wyrażone wprost. Utożsamiany jest w końcu z gronem artystów unikających jakiejkolwiek dosłowności. Kubrick sam zresztą podkreślał:

że w filmie czy w sztuce teatralnej wyrażenie jakiejś prawdy o życiu musi następować w sposób zakamuflowany, tak aby uniknąć wszelkich jednoznacznych konkluzji i gładkich frazesów. Poglądy, jakie mają być przekazane, muszą organicznie splatać się z samym życiem i niepostrzeżenie przenikać do świadomości widza. Ważne i trafne myśli mają tak bardzo złożony charakter, że nie można ich forsować. Powinna odkryć je publiczność, a towarzyszący temu odkryciu dreszcz emocji nada im jeszcze większą wagę 4 .

Współscenarzystka Lśnienia - Diana Johnson - dodawała też, że zdaniem Kubricka „dany utwór może być pocięty na małe, jakby niezależne od siebie fragmenty, i że każda $\mathrm{z}$ tych partii może mieć samoistne

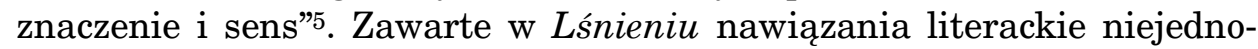
krotnie korespondują z poszczególnymi płaszczyznami interpretacyjnymi, które można wyróżnić w obrębie filmu Kubricka. Jack Torrance nieprzypadkowo dwukrotnie przemawia do tajemniczego barmana Lloyda słowami tytułu wiersza Rudyarda Kiplinga. Brzemię białego człowieka (The White Man's Burden) odnosi się do amerykańskiego podboju Filipin i usprawiedliwia kolonizację $\mathrm{w}$ imię niesienia kaganka oświaty i misji

3 M. Wedemann, Zobrazować niewidzialne. Symbolika religijna $w$ „Oczach szeroko zamkniętych", [w:] Język religii dawniej i dziś (w kontekście teologicznym i kulturowym). V. Materiaty $z$ konferencji. Gniezno 22-24 września 2008, pod red. P. Bortkiewicza, S. Mikołajczaka i M. Rybki, Poznań 2009, s. 475 (Biblioteczka Poznańskich Studiów Polonistycznych Serii Językoznawczej, t. 39).

${ }^{4}$ S. Kubrick, Powieści i filmy, przeł. P. Kopański, „Film na Świecie” 1993, nr 394/395, s. 57.

${ }^{5}$ Mówi Diane Johnson, scenarzystka „Shining”, przeł. I. Dembowski, „Film na Świecie” 1981, nr 273-274, s. 40 (wywiad przeprowadził D. Barbier). 
cywilizowania „dzikich”. Utwór Kiplinga stanowi też świetny kontekst przy uwzględnieniu socjologicznej wymowy filmu, w której reżyser pokusił się o bardziej wnikliwe spojrzenie na naturę samego człowieka. Wielopoziomowy charakter obrazu Kubricka pozwalał badaczom spoglądać na Lśnienie z rozmaitych perspektyw. Obecna w filmie koncepcja czasu była jedną z najbardziej nurtujących kwestii dla wielu komentatorów. Przyjrzenie się $\mathrm{z}$ większą uwagą odniesieniom literackim $\mathrm{w}$ dziele Kubricka pozwala zgłębić obecny w Lśnieniu zagadkowy aspekt czwartego wymia$\mathrm{ru}^{6}$. Jedna $\mathrm{z}$ jego wypowiedzi zachęca zresztą odbiorcę do poszukiwania pozafilmowych nawiązań:

Zamiast wznosić dekoracje wymyślone i narysowane przez scenografa, co zresztą najczęściej szokuje sztucznością i dekoracją operową, lepiej jest dać coś prawdziwego, realnego, żeby ludzie mogli uwierzyć w tę historię. Musiałem umieścić ją w scenerii, która wyglądałaby na prawdziwą, istniejącą w rzeczywistości i oświetloną jak dokument, światłem naturalnym, a nie owym światłem, zafałszowanym i dramatycznym jakie najczęściej spotykamy w dreszczowcach. Można by to porównać z metodą pisarską Franza Kafki albo Borgesa [wyróżnienie - K.K.], z tą prostotą i naturalnością wykluczającą wszelką barokowość, gdzie fantastyka traktowana jest w sposób zwyczajny, codzienny?

Kubrick w wywiadzie udzielonym tuż po premierze Lśnienia jednoznacznie wskazywał na znajomość prozy Borgesa, zestawiając swój sposób ukazywania rzeczywistości z jego metodą pisarską ${ }^{8}$. Znaczący jest w tym przypadku fakt, że w książce Stephena Kinga, czyli w pierwowzorze literackim filmu, nie odnajdziemy motywu labiryntu - stanowiącego

${ }^{6}$ Wśród odniesień literackich w Lśnieniu celowo pomijam książkę Stephena Kinga, będącą pierwowzorem literackim filmu, ponieważ podzielam opinię, że Kubrick „materiał literacki traktował jedynie jako punkt wyjścia dla swoich filmów” (A. Lewicki, Stanley Kubrick. Dychotomie i paradoksy, [w:] Kino amerykańskie. Twórcy, red. E. Durys i K. Klejsa, Kraków 2006, s. 107). Identyczne stanowisko prezentuje Alicja Helman: „Właściwie trudno byłoby powiedzieć, iż w filmie Lśnienie dokonano adaptacji powieści Kinga. Została ona jedynie w pewnym stopniu wykorzystana do stworzenia autonomicznego wobec niej filmu" (A. Helman, Twórcza zdrada: Filmowe adaptacje literatury, Poznań 1998, s. 100).

7 Mówi Stanley Kubrick, przeł. I. Dembowski, „Film na Świecie” 1981, nr 273-274, s. 35 (wywiad przeprowadził J.P. Oudart). „Fantastyka traktowana [w filmach Kubricka K.K.] w sposób zwyczajny, codzienny" i pozbawiona znamion barokowości nie została, niestety, dostrzeżona przez Piotra Kletowskiego, który utrzymuje, że w Lśnieniu występuje horror phisicus - wyzbyty z jakiegokolwiek metafizycznego wymiaru. W dalszej części wywodu wskazuję na liczne osobliwości filmu Kubricka, jakie przeczą tezie Kletowskiego. Por. P. Kletowski. Filmowa odyseja Stanleya Kubricka, Kraków 2006, s. 179-316.

$8 \mathrm{Z}$ równą dociekliwością należałoby spojrzeć na obecność w cytowanym wywiadzie nazwiska Franza Kafki. W dalszej części artykułu omówiony zostanie pojawiający się w Lśnieniu motyw drzwi, który był też w polu zainteresowań badaczy zajmujących się twórczością praskiego pisarza. 
jeden $\mathrm{z}$ naczelnych symboli $\mathrm{w}$ twórczości Argentyńczyka ${ }^{9}$. Głowiński zwraca uwagę na labiryntowy charakter czasu obecny w twórczości Borgesa, który w największym stopniu ujawnia się w opowiadaniu Ogród o rozwidlających się ścieżkach. Myśl badacza jest kluczowa dla zrozumienia wszelkich powiązań między Lśnieniem a prozą Argentyńczyka. Stanowi w dużej mierze punkt wyjścia dla rozważań dotyczących koncepcji współistnienia $\mathrm{w}$ filmie światów równoległych, które wraz z rozwojem akcji zaczną się coraz bardziej przenikać.

Temat jest niewątpliwie bardzo rozległy. Wymaga, aby w pierwszej kolejności przybliżyć zarówno prozę, jak i samą osobę Borgesa. Dopiero wtedy rozwinąć można kwestię związaną $\mathrm{z}$ przenikaniem się $\mathrm{w}$ filmie różnych płaszczyzn czasowych, co zresztą często analizowane było przez komentatorów twórczości Kubricka. Zestawienie Lśnienia z prozą Borgesa, a w szczególności omówienie powracającej w utworach Argentyńczyka labiryntowej natury czasu, pozwala na wyjaśnienie wielu osobliwości filmu istotnych dla jego interpretacji. Nieporozumieniem byłoby chyba pominięcie kilku interesujących uwag dotyczących symbolicznego znaczenia samego labiryntu. Niekwestionowanie najlepszym przewodnikiem będzie w tym przypadku świetne studium Paola Santarcangeliego pt. Księga labiryntu ${ }^{10}$.

\section{Borges a problem czasu}

Zadziwiający był los Ts'ui Pena [...] porzucił [...] wszystko, aby stworzyć książkę i labirynt. [...] ogrodem o rozwidlających się ścieżkach była chaotyczna powieść [...] Ogród o rozwidlajacych się ścieżkach jest obrazem niekompletnym, ale nie fałszywym, wszechświata takiego, jak pojmował go Ts'ui Pen. W odróżnieniu od Newtona i Schopenhauera pański przodek nie wierzył w czas jednolity, absolutny. Wierzył w nieskończone serie czasów, w rosnącą i zawrotną sieć czasów zbieżnych, rozbieżnych i równoległych. Ta przędza czasów, które zbliżają się, rozwidlają, przecinają i które przez wieki o sobie nie wiedzą, obejmuje wszystkie możliwości ${ }^{11}$.

Borges w jednym ze swoich esejów - znanym pod nazwą Nowa refutacja czasu (ewentualnie tłumaczonym też jako Nowy dowód na nieistnienie czasu) - wyjawia, że odrzuca istnienie jednego tylko czasu, w któ-

${ }^{9}$ M. Głowiński, Mity przebrane, Kraków 1994, s. 154.

10 P. Santarcangeli, Księga labiryntu, przeł. I. Bukowski, red. naukowa A. Krawczuk, Warszawa 1982.

11 J.L. Borges, Opowiadania, przeł. Z. Chądzyńska, A. Sobol-Jurczykowski, K. Piekarec, K. Wojciechowska, S. Zembrzuski, Kraków 1978, s. 84, 86 i 89. 
rym wszystkie fakty miałyby się ze sobą zazębiać ${ }^{12}$. Punktem wyjścia dla rozważań pisarza są spostrzeżenia Berkeleya i Hume’a na temat percepcji rzeczywistości. Skoro świat zostaje wpierw przefiltrowany przez zmysły, a następnie umysł człowieka i stanowi pewnego rodzaju projekcję każdego z nas, w jaki zatem sposób - zapytują filozofowie - możemy mówić o istnieniu przestrzeni absolutnej, która nie byłaby czysto subiektywnym postrzeganiem czy raczej odbieraniem rzeczywistości? Borges, kierując się podobną logiką myślenia, zauważa, że ,jeżeli czas jest procesem umysłowym, to jak mogą go podzielać tysiące ludzi czy choćby dwaj różni ludzie?”13. Sama „[...] teoria względności wyeliminowała ostatecznie ideę absolutnego czasu"14 - o czym pisze Stephen Hawking w Ilustrowanej krótkiej historii czasu. W rozdziale Tunele $i$ podróże $w$ czasie rozważa nawet możliwość przemieszczania się „między różnymi obszarami czasoprzestrzeni", co Albert Einstein i Nathan Rosen uznali już w 1935 roku za prawdopodobne ${ }^{15}$. Borges przyznaje też, że idea refutacji czasu występuje w wielu jego utworach, wskazując między innymi cytowany na wstępie Ogród o rozwidlających się ścieżkach ${ }^{16}$. Zdaniem Michała Głowińskiego labirynt w twórczości pisarza:

[...] nie jest [...] tylko kategorią przestrzenną, odnosi się także [...] do czasu. [...] momenty i dłuższe odcinki czasowe [...] wzajemnie się przenikają, w taki jednak sposób, że wykluczają wszelkie bezpośrednie podporządkowanie pierwszych dru-

12 J.L. Borges, Nowa refutacja czasu, [w:] tegoż, Dalsze dociekania, przeł. A. Sobol-Jurczykowski, Warszawa 1999, s. 259. Kwestia czasu niejednokrotnie jeszcze pojawiała się w wypowiedziach oraz działalności Borgesa: „To ambicja człowieka, jak sądzę: myśl o życiu poza czasem. Nie wiem jednak, czy jest to możliwe, chociaż dwa razy [...] w moim długim życiu czułem, że istnieję poza czasem - to znaczy, że jestem wieczny. Oczywiście nie wiem, jak długo trwało to wrażenie, bo przecież byłem poza czasem. Nie mogę też tego opisać, ale było to coś bardzo pięknego" (J.L. Borges, O. Ferrari, W dialogu I, przeł. E. Nawrocka, Gliwice 2007, s. 30). Borges i Adolfo Bioy Casares założyli też czasopismo pt. „Destiempo” [Bezczas] (J.L. Borges, O. Ferrari, dz. cyt., s. 32).

13 J.L. Borges, Nowa refutacja czasu..., s. 260-261.

14 S. Hawking, Ilustrowana krótka historia czasu, przeł. P. Amsterdamski, Poznań 1996, s. 32 .

15 Tamże, s. 203. Zbieżną opinię formułuje Leszek Kołakowski: „pytanie, na czym polega realność czasu, jest pytaniem dręczącym, na które nie umiem odpowiedzieć i może nikt nie umie. Powiedzenie, że coś jest wcześniej, a coś jest później, nie zakłada, iż jest taka realność jak czas. Prawdopodobnie możemy się obejść bez uznawania tej realności. A jednak mimo wszystko wolno nam mieć poczucie jakiejś niedocieczonej zagadki w samej obecności czasu. [...] My, uczniowie Leibniza, powiadamy, że czas jest zjawiskiem dobrze ugruntowanym, ale zjawiskiem, nie należy więc do rdzenia bytu, nie jest rzeczywistością absolutną”. L. Kołakowski i Z. Mentzel, Czas ciekawy, czas niespokojny, t. 2, Kraków 2008, s. 185 i 187.

16 J.L. Borges, Nowa refutacja czasu..., s. 252. 
gim. Tak jak w labiryncie sensu stricto naruszone bywają zazwyczaj wszelkie tradycyjne układy przestrzenne, tak tutaj zakłóceniu podlegają te relacje temporalne, które wydają się nam oczywistymi atrybutami czasu „normalnego”. Zanika ciągłość i gubi się perspektywa, która pozwalałaby ów potok czasu porządkować, ujawniać jego kierunek, wskazywać wymiary składających się nań elementów. [...] Jednym z głównych czynników, decydujących o labiryntowości czasu, jest to, że niejasny pozostaje jego status ontologiczny. Zacierają się przedziały między czasem „obiektywnym” i czasem „subiektywnym”, między czasem, w którym bohater żyje, a tym, jaki w danym momencie przeżywa. Tak kształtowany, czas nie może już mieć charakteru linearnego, podobnie jak nie ma go układająca się we wzór labiryntowy przestrzeń. Zarysowują się wyraźne analogie: i czas rozpada się na pokrętne korytarze, których wzajemne stosunki kwestionują to wszystko, co łączyłoby się z wyobrażeniami świata, zorganizowanego według reguł geometrii ${ }^{17}$.

W twórczości samego Kubricka także podkreślano „próbę doprowadzenia do współistnienia różnych planów czasowych”, które „przybierałyby formę krzyżujących się linii” i „zbiegałyby się w jednym wyznaczonym punkcie"18. Scena pojawiająca się w zakończeniu 2001: Odyseja kosmiczna przekonuje, że podobny sposób myślenia o czasie rzeczywiście obecny jest u Kubricka.

Umberto Eco wyznacza trzy typy labiryntu, zwracając w szczególności uwagę na ostatni, określany mianem „sieci”, „w której każdy punkt może zostać połączony z każdym innym punktem [...], a proces łączenia jest jednocześnie ciągłym procesem korekty połączeń"19, co oznacza, że „struktura takiego labiryntu byłaby zawsze różna od tej, jaką miał chwilę wcześniej, i za każdym razem można by się po nim poruszać wzdłuż innych linii”20. Dla dalszego toku rozważań ważne jest dostrzeżenie, że płaszczyzna czasowa w Lśnieniu przybiera wspomnianą „formę krzyżujących się linii”, czyli po prostu „sieci”.

\section{W sieci różnych czasów}

Zastanawiające jest spotkanie głównego bohatera filmu Kubricka z barmanem Lloydem w sali Gold Room. Po raz pierwszy dopatrywać się można oznak wskazujących na stopniowe popadanie Jacka w szaleństwo.

${ }_{17}$ M. Głowiński, dz. cyt., s. 205-206.

18 G.P. Brunetta, Filmowa odyseja Stanleya Kubricka, tłum. U. Franczyk, [w:] Stanley Kubrick w opinii krytyki zagranicznej, red. D. Zielińska, Warszawa 1989, s. 65-66.

19 U. Eco, Od drzewa do labiryntu, przeł. G. Jurkowlaniec, M. Surma-Gawłowska, J. Szymanowska i A. Zawadzki, Warszawa 2009, s. 49.

20 Tamże. 
Podobne wrażenie wzmacnia tajemnicze zniknięcie barmana wraz z alkoholem, jaki serwuje on swemu klientowi, w momencie pojawienia się Wendy. Kolejnym sygnałem obłędu bohatera jest sekwencja, w której jego żona odkrywa, że na kartach rzekomej powieści Jacka wielokrotnie powtórzone zostaje jedno zdanie. Trudno zatem nie traktować tajemniczych postaci pojawiających się w hotelu jako wytworu obłąkanego umysłu niedoszłego pisarza. Jednak pewne elementy mogłyby przeczyć podobnej tezie, jak chociażby scena, która sugeruje uwolnienie zamkniętego w spiżarni Jacka przez Delberta Grady'ego. Wszystko, co przecież wydawało się zwykłym urojeniem, nagle nabierze niezaprzeczalnych znamion czegoś rzeczywistego i realnego.

Warto jednak zauważyć, że w scenie z Lloydem nie występuje ani jedno ujęcie wskazujące na subiektywny punkt widzenia Jacka. Kubrick podkreśla coś wręcz absolutnie odwrotnego. Główny bohater zostaje ukazany na tle sali Gold Room z perspektywy, którą można zestawić ze wzrokiem pojawiającego się barmana. Następne ujęcie przedstawia postać Lloyda w planie amerykańskim. Po chwili kamera robi wyraźny odjazd aż za plecy Jacka, co oznacza, że ustawienie obiektywu nie jest zgodne z punktem widzenia głównego bohatera. Sposób zainscenizowania tej sceny przez Kubricka przeczyłby hipotezie, jakoby widz oczami Torrance'a przyglądał się wydarzeniom rozegranym w sali Gold Room. Omar Calabrese, w związku ze sceną przy barze, dostrzega sugestię istnienie odrębnych „,́́wiatów możliwych”, które są względem siebie całkowicie przenikalne $^{21}$. Jack wypowiada się nawet o Lloydzie jako o najlepszym barmanie „od Timbuktu po Portland w stanie Maine, czy nawet Portland w stanie Oregon"22. Kwestia niezwykle zastanawiająca, ponieważ sugerowałaby, że bohaterowie mieli już kiedyś okazję się spotkać.

Równie zdumiewające jest pojawienie się w filmie osoby Grady'ego, czyli według słów Jacka - poprzedniego stróża hotelu Overlook. Obie postacie zetkną się ze sobą na balu z lat dwudziestych, który odbywa się $\mathrm{w}$ opustoszałym hotelu w sali Gold Room. Niezmiernie istotna, a bardzo łatwa do przeoczenia, staje się różnica imion, jakie pojawiają się w związku z osobą Grady'ego. W rozmowie z Ullmanem na początku filmu zostanie on nazwany Charlesem, natomiast w późniejszej części Lśnienia Jack w tajemniczej postaci rozpozna swego poprzednika i, co zaskakujące, zacznie zwracać się do swojego rozmówcy imieniem Delbert. Podobne rozróżnienie nie pojawia się jednak w książce Stephena Kinga. Kwestia ta wygląda o wiele mniej zagadkowo przy uwzględnieniu kon-

21 O. Calabrese, „Światy możliwe” Kubricka, czyli poetyka drzwi, tłum. U. Franczyk, [w:] Stanley Kubrick w opinii krytyki zagranicznej..., s. 127.

22 0:49'28" - 0:49'33". 
cepcji czasu opisywanej przez jednego z bohaterów Ogrodu o rozwidlajacych się ścieżkach:

We wszystkich narracjach za każdym razem, gdy człowiek ma do czynienia z rozmaitymi możliwościami, wybiera jedną i wyklucza inne; w narracji nierozwikłanego Ts'ui Pena - równocześnie - wszystkie. Tworzy w ten sposób rozmaite przyszłości, które również mnożą się i rozwidlają. Stąd sprzeczności powieści. [...] W dziele Ts'ui Pena mają miejsce wszystkie rozwiązania. [...] Ta przędza czasów, które zbliżają się, rozwidlają, przecinają i które przez wieki o sobie nie wiedzą, obejmuje wszystkie możliwości. Nie istniejemy w większości tych czasów; w niektórych istnieje pan, a ja nie; w innych ja, a pan nie; w innych istniejemy obaj. W tym, który zsyła mi pomyślny przypadek, przyszedł pan do mojego domu; w innym, przechodząc przez ogród, znalazł mnie pan martwego; w innym ja mówię te same słowa, ale jestem jaką̧́ omyłką, widmem ${ }^{23}$.

Utwór Borgesa zakłada zatem istnienie odrębnych i rozmaitych tożsamości poszczególnych ludzi w zależności od czasu, w którym się znajdują ${ }^{24}$. W zestawieniu $\mathrm{z}$ opowiadaniem bardzo łatwo jest więc uzasadnić kwestię zagadkowej zamiany imion. Bez większego problemu można wytłumaczyć, w jaki sposób Delbert Grady pojawia się na balu w roli kelnera i dlaczego Jack rozpoznaje w jego osobie postać stróża hotelu Overlook, który w 1970 roku zamordował całą swoją rodzinę, a następnie popełnił samobójstwo. Nietrudno także odpowiedzieć na pytanie, dlaczego, zdaniem rzekomego poprzednika, to Jack zawsze pełnił funkcję dozorcy. Delbert Grady zaprzeczy też początkowo, jakoby dopuścił się opisanej zbrodni. Później opowie on jednak, że musiał ukarać swoje córki, ponieważ jedna z dziewczynek chciała podpalić hotel. Żona próbowała go powstrzymać, więc podzieliła los dzieci. Druga część rozmowy, paradoksalnie, odpowiada dramatycznym wydarzeniom, jakie miały rzekomo miejsce w hotelu Overlook. Pozornie trudno wytłumaczyć, skąd biorą się pewne sprzeczności, które pojawiają się w kolejnych wypowiedziach Grady'ego. Znaczące jest zatem zrozumienie refleksji Umberta Eco dotyczącej „sieci”, a tym samym pamiętanie, że: „struktura takiego labiryntu byłaby zawsze różna od tej, jaką miał chwilę wcześniej, i za każdym razem można by się po nim poruszać wzdłuż innych linii”25. Odmienną tożsamość Grady’ego można zapewne traktować jako jedną z dróg w Ogrodzie o rozwidlających się

23 J.L. Borges, Opowiadania..., s. 86-87 i 89.

${ }^{24}$ Zresztą wniosek ten potwierdza również jedna z wypowiedzi samego Borgesa, która ukazuje też inne punkty wspólne między Lśnieniem a prozą pisarza: „Zaczynam się czuć [...] jak coś w rodzaju fabryki opowiadań o zamienionych tożsamościach, labiryntach, [...], lustrach, o ludziach nie będących sobą, tylko kimś innym, o tym, że wszyscy ludzie są jednym człowiekiem albo że ktoś sam dla siebie jest śmiertelnym wrogiem". R. Burgin, Rozmowy z Jorge Luisem Borgesem, przeł. M. Kłobukowski, Gdańsk 1993. s. 128.

25 U. Eco, dz. cyt., s. 49. 
ścieżkach ${ }^{26}$. Koncepcja labiryntowości czasu tłumaczyłaby w końcu przecięcie się losów Jacka Torrance'a, Delberta Grady'ego, a także osób biorących udział w balu, który ma miejsce w latach dwudziestych.

Zresztą sceny rozgrywające się w sali Gold Room nie są jedynymi w filmie, jakie świadczyłyby o dążeniu Kubricka do ,jednoczesnego skąpania różnych elementów fabuły w rzece wielu czasów"27. Między pewnymi częściami obrazu występuje w końcu zagadkowa ciągłość. W jednej scenie widzimy sfrustrowanego Jacka, który odbija o ścianę piłkę tenisową, a w innej identyczny rekwizyt w tajemniczych okolicznościach pojawi się ponownie przed bawiącym się Dannym. O szczególnej roli tego przedmiotu w filmie świadczy zresztą sekwencja, jaka znalazła się w pierwszej wersji Lśnienia, chociaż z czasem Kubrick powziął decyzję o jej usunięciu. Mowa o scenie, w której Ullman w zakończeniu filmu odwiedzał Wendy i chłopca w szpitalu, gdzie wręczał Danny'emu identyczną piłkę ${ }^{28}$. Również w przedstawieniu wydarzeń mających miejsce w łazience pokoju 237 sugeruje się występowanie czasów równoległych. Na początku z wanny wyjdzie postać pięknej kobiety, której lustrzane odbicie zdradzi zupełnie odmienną i odpychającą fizjonomię jej osoby. Tajemnicze „widmo” zacznie złowieszczo kroczyć za Jackiem. W przebitkach pojawi się natomiast ujęcie przedstawiające wynurzającą się z wanny „zjawę”. Montaż kolejnych ujęć wskazuje zatem, że zagadkowa „persona” od początku stanowiła tajemnicze „widmo”. Interesujące byłoby przecież myślenie o tej scenie w ramach „sieci”, której struktura ulega ciągłej metamorfozie.

Kwestia zagadkowości czasu najmocniej wybrzmiewa w zakończeniu Lśnienia. W ostatnim ujęciu widzimy postać Jacka na jednej z fotografii, jaka znajduje się przy wejściu do hotelu. Zdjęcie datowane jest na rok 1921. Całej scenie towarzyszy utwór Midnight, The Stars and You, który zresztą można było usłyszeć w sali Gold Room podczas sekwencji balu, pomimo że wspomniana kompozycja została nagrana dopiero $\mathrm{w}$ latach trzydziestych. W końcowych ujęciach wszystkie umieszczone w holu meble przykryte są białym materiałem. Znika również czerwona kanapa, która znajdowała się tuż pod zawieszonymi na ścianie zdjęciami. Wspomniana fotografia została $\mathrm{w}$ dodatku we wcześniejszej części filmu zastąpiona przez Kubricka zupełnie inną (wystarczy przyjrzeć się scenie, w której Hallorann, wezwany przez Danny'ego za sprawą jego telepatycznych zdolności, ponownie zjawi się w hotelu Overlook). Tych kilka znikomych uwag w żadnym stopniu nie pozwala jednoznacznie określić,

${ }^{26} \mathrm{~W}$ związku z zagadnieniem czasu obecne są „hipotezy, że istnieje wiele alternatywnych historii, które rozgałęziają się w pewnych ważnych zdarzeniach”. S. Hawking, dz. cyt., s. 208.

27 G.P. Brunetta, dz. cyt., s. 65.

${ }^{28}$ Imperfect Symmetries, <http://kubrickfilms.tripod.com/id4.html>, dostęp: 09.12.2014. 
kiedy rozgrywa się akcja końcowej sceny. Trudno jest nawet odpowiedzieć na pytanie, w jakim pomieszczeniu hotelu Overlook wyeksponowana fotografia została wykonana. Wielu zapewne wskazałoby na salę Gold Room, gdzie Jack uczestniczył w balu z lat dwudziestych. Podobnej hipotezie przeczy już sama architektura wnętrza widoczna na zdjęciu. Reżyser jednak doskonale manipuluje przestrzenią, a stroje pozujących na zdjęciu ludzi utwierdzają widza w błędnym przeświadczeniu.

Tajemnicza fotografia obecna w ostatnim ujęciu filmu nie pojawia się w powieści Stephena Kinga i jest w pełni autorskim pomysłem samego Kubricka. Obecny w zakończeniu Lśnienia zagadkowy charakter czasoprzestrzeni był przez twórcę w pełni zamierzony, ale element tajemnicy tyczący się natury czwartego wymiaru towarzyszy widzowi już od początku filmu. Wystarczy przyjrzeć się scenie, kiedy Jack po raz pierwszy pojawi się w hotelu. Za tablicą Gold Room znajdują się zamknięte drzwi, za którymi dostrzec można tajemniczą parę ubraną w strój balowy z lat dwudziestych ${ }^{29}$. Widmo zamordowanych w 1970 roku bliźniaczek również ma na sobie sukienki z tego okresu ${ }^{30}$. Zagadkowe bywa także zróżnicowanie wystroju poszczególnych pomieszczeń hotelu Overlook. Pokój 237, kwatera zajmowana przez rodzinę Torrance'ów, sala Gold Room, łazienka, w której Jack rozmawia z Gradym - pod względem aranżacji wnętrza te zupełnie do siebie nie pasują.

Dla rozważań dotyczących przenikania się różnych „światów” niezwykle intrygujący okazuje się fragment, w którym Hallorann oprowadza Wendy i Danny'ego po kuchni. Kucharz w pewnym momencie wskazuje pomieszczenie, gdzie znajduje się chłodnia. Chwyta za klamkę i następuje cięcie montażowe. W kolejnym ujęciu widać od wewnątrz, jak drzwi otwierają się $\mathrm{w}$ lewą stronę, chociaż wcześniejszy fragment wyraźnie wskazywał, że ruch powinien odbyć się w przeciwnym kierunku. Hallorann opowiada o zawartości chłodni i bohaterowie opuszczają pomieszczenie. Ponownie następuje cięcie montażowe. Kamera po raz kolejny znajduje się na korytarzu kuchni hotelu Overlook. Tym razem strona, po jakiej znajduje się klamka zamykanych przez kucharza drzwi, jest zgodna $\mathrm{w}$ zestawieniu $\mathrm{z}$ poprzednim ujęciem, które pokazywało chłodnię od środka. Jednak łatwo się domyśleć, że przestrzeń za bohaterami różni się od tła, jakie towarzyszyło im, zanim kamera przeniosła się do wspomnianego wnętrza. Początkowo trudno jednoznacznie odpowiedzieć, skąd wynikła cała zmiana związana z tym nietypowym przemieszczeniem. Kamera powoli cofa się, a bohaterowie podążają jej śladem. Nagle po prawej stronie dostrzec można stół z różnymi naczyniami, który znajdował się

\footnotetext{
29 Tamże.

30 Tamże.
} 
tuż przy drzwiach, jakie na początku opisywanej sceny miał otworzyć Hallorann. Kubrick za sprawą konkretnego rekwizytu pozwala widzowi na zorientowanie się w przestrzeni całego fragmentu.

Opisaną sytuację warto sprowadzić do najprostszej myśli - kucharz chce pokazać bohaterom chłodnię, chwyta za klamkę drzwi i nagle akcja przenosi się do przeciwległego pomieszczenia ${ }^{31}$. Dalsza część Lśnienia w ewidentny sposób wskazuje, że właśnie za sprawą drzwi możliwe staje się przeniknięcie do „równoległej”, ale pytanie - czy w pełni odrębnej rzeczywistości ${ }^{32}$. Jack spotka przecież postać tajemniczego barmana Lloyda dopiero po tym, jak Danny przekroczy próg pokoju 237. Wystarczy, żeby chłopiec próbował przekręcić gałkę $\mathrm{w}$ drzwiach wspomnianego apartamentu, aby w jednej z kolejnych scen pojawiło się przed nim widmo bliźniaczek i ukazało bohaterowi swoją krwawą wizję. Sytuacja stanie się jeszcze bardziej groźna, kiedy także Jack sprawdzi, co kryje się w pokoju 237. Dopiero wtedy wszystkie „ścieżki” czasu zaczną się przenikać, co doskonale zaprezentowane zostanie za sprawą sceny balu w sali Gold Room. Kierując się podobnym tropem interpretacyjnym, warto byłoby się również zastanowić, jak bardzo symbolicznego charakteru nabrałaby scena, w której Delbert Grady otwiera Jackowi zaryglowane drzwi od spiżarni. Równie ciekawe, że główny bohater w jednej z następnych scen będzie próbował siekierą roztrzaskać drzwi, jakie oddzielają go od reszty rodziny. Zdolność tytułowego „lśnienia”, które przejawiają Danny, Halloran oraz Jack, tłumaczy, dlaczego Wendy jako ostatnia osoba $\mathrm{w}$ filmie doświadcza przenikania się różnych czasów.

\section{Labirynt a wieczność}

Współistnienie w Lśnieniu rozmaitych płaszczyzn czasowych ciekawie koresponduje z następującą wypowiedzią Borgesa: „Wieczność - pisałem o tym w opowiadaniu pod tytułem «Alef» - to, powiedzmy, bardzo zuchwała hipoteza, że istnieje chwila i że w owej chwili zbiegają się: cała

$31 \mathrm{~W}$ filmie dochodzi też do równoległego przemieszczenia tablicy z napisem „The Gold Room”, co, jak zauważa Krzysztof Kozłowski, nie jest przypadkowe: „Jakby dla potwierdzenia, że obydwa światy zaczynają się już przenikać, tablica z napisem «The Gold Room» zostanie przeniesiona z prawej na lewą stronę podłużnej osi hallu; na swoje miejsce powróci ona dopiero na koniec filmu”. K. Kozłowski, Muzyka i horror. „Lśnienie” Stanleya Kubricka, „Images” 2009-2010, vol. 13-14, s. 52.

32 Podobne przeczucie w stosunku do roli drzwi w filmie Lśnienie ujawnia też Omar Calabrese: „Innym przykładem przenikalności światów są prawie wszystkie sekwencje, w których występują drzwi. [...] Ten szereg drzwi zdaje się umożliwiać przenikanie światów”. O. Calabrese, dz. cyt., s. 128. 
nasza przeszłość, wszystkie nasze «wczoraj», jak powiedział Szekspir, cała teraźniejszość i cała przyszłość. Ale to był atrybut boskości”33. Podobną uwagę względem rozumienia słowa wieczność wypowiada Leszek Kołakowski:

W teologii chrześcijańskiej zakłada się, że Bóg jest wieczny nie w tym sensie, że ma nieskończone istnienie bez początku i końca, ale $\mathrm{w}$ tym znaczeniu, że nie ma w nim ani przeszłości, ani przyszłości, tylko wieczna teraźniejszość, jak to $\mathrm{w}$ średniowieczu się mówiło - nieruchome teraz. I że to wynika jakby z samej doskonałości Boga. Skoro bowiem Bóg jest doskonały, to nie może upośredniczać stosunku do samego siebie ani tak, jak my to robimy, przez pamięć, czyli przez ogląd przeszłości, ani przez antycypację, czyli przez wiedzę o przyszłości. Skoro to niemożliwe, musi On mieć inny rodzaj istnienia, o którym możemy coś sobie powiedzieć, filozofując, ale w który przecież sami nie potrafimy wejść. Mistycy mieli poczucie, że uczestniczą w nim chwilowo ${ }^{34}$.

W artykule Demoniczna transcendencja. Motyw faustowski w „Lśnieniu” Stanleya Kubricka szczegółowo omawiałem postawę Jacka. Analizując jego lęki i pragnienia, dowodziłem, że w twórczych aspiracjach głównego bohatera kryje się pragnienie przezwyciężenia własnych ograniczeń ${ }^{35}$. Współistnienie różnych płaszczyzn czasowych $\mathrm{w}$ zakończeniu 2001: Odyseja kosmiczna w równym stopniu odpowiada idei przekraczania przez istotę ludzką ziemskich uwarunkowań i w efekcie narodzin nowego rodzaju człowieka - tzw. „gwiezdnego dziecka” („star child”). Postawa Jacka i jego twórcze aspiracje odzwierciedlają dążenia bohatera ku wieczności. Michel Ciment zauważa, że:

W filmie ma miejsce kondensacja czasu: początkowo operuje się miesiącami, potem dniami i godzinami (autor wskazuje na rozdziały, jakie pojawiają się w filmie - K.K.). Tak więc w Lśnieniu stopniowo redukuje się czas. [...] Wydaje mi się zatem, że podstawowym problemem Kubricka jest zmaganie się z czasem. Jego bohater musi osiągnąć pewien cel, ale nie starcza mu na to czasu. Problem ten dotyczy zarówno samego Kubricka - jego pracy i życia osobistego, jak i jego filmów. Jak wszystkie osoby odczuwające tak głęboko problem czasu, jest on zafascynowany nieśmiertelnością, pojmowaną jako skutek zanegowania czasu. W Lśnieniu pojawia się właśnie idea nieśmiertelności. [...] podstawowym problemem jest zanegowanie śmierci, jej przezwyciężenie. Każdy punkt, skierowany

33 J.L. Borges, O. Ferrari, dz. cyt., s. 31. Zob. też J.L. Borges, Historia wieczności, przeł. A. Elbanowski, Warszawa 2006, s. 11-12.

${ }^{34}$ L. Kołakowski, Z. Mentzel, dz. cyt., s. 186. Zob. też Augustyn Aureliusz, Wyznania, przeł. Z. Kubiak, Warszawa 1982, s. 225-227.

35 Zob. K. Kościelski, Demoniczna transcendencja. Motyw faustowski w „Lśnieniu” Stanleya Kubricka, „Przestrzenie Teorii” 2013, nr 19, s. 153-170. 
przeciwko czasowi, jest walką ze śmiercią. Sądzę, że kino Kubricka wyraża w głęboki sposób ten konflikt ${ }^{36}$.

Zdaniem Michela Cimenta obsesją Kubricka jest czas, z którym Jack postanawia walczyć za pomocą twórczego działania. Zawarta w Lśnieniu koncepcja czwartego wymiaru ma więc na celu pokazać pełną złożoność motywacji kierujących głównym bohaterem.

Nie bez znaczenia pozostaje symboliczna śmierć Jacka w środku ogrodowego labiryntu, gdzie zbiegają się wszystkie „ścieżki”. Ukazana na końcu filmu fotografia sugeruje, że Jack dołączył do świata, w którym przenikają się wszelkie drogi czasu ${ }^{37}$. Dotarcie do wnętrza labiryntu jest często pojmowane jako zwycięstwo nad przestrzenią i czasem ${ }^{38}$, co w oczywisty sposób wiąże się z dążeniem głównego bohatera do wieczności. Już w pierwszej scenie pojawia się zresztą identyczna sugestia. Zdjęcia otwierającej sekwencji, w której Jack podąża serpentynami w stronę hotelu Overlook, ukazują drogę zwaną Going-to-the-Sun Road. Nazwa wywodzi się od góry, jaka zlokalizowana jest tuż obok wspomnianej szosy. Swoje miano zawdzięcza legendzie opowiadającej o Indianinie, który zdobył wysoko położony szczyt i połączył się ze słońcem w wieczności ${ }^{39}$. Wątek ten zostanie nawet zwerbalizowany w scenie, w której Jack, trzymając swego syna na kolanach, powie mu, że chciałby zostać w hotelu Overlook „na zawsze”. Kwestia bohatera brzmi jak echo słów wypowiadanych w poprzedniej scenie przez widmo bliźniaczek, które nawiedza Danny'ego. Warto zauważyć, że zarówno Jack, jak i dziewczynki mają na sobie w odpowiednich scenach ubrania koloru niebieskiego, łączonego z transcendencją i ukazywaniem się duchów ${ }^{40}$. Co ciekawe, we wspo-

${ }^{36}$ M. Ciment, Przestrzeń $i$ czas $w$ dziełach Kubricka, przeł. U. Franczak, [w:] Stanley Kubrick w opinii krytyki zagranicznej..., s. 115-117. Por. też P. Kletowski, dz. cyt., s. 302-303.

${ }^{37}$ Centrum labiryntu według Paolo Cherchi Usai „nie jest niczym innym jak punktem zetknięcia się wszystkich możliwych dróg (wszystkich możliwych do wyobrażenia sobie czasów w Overlook Hotel)”. P.C. Usai, Kubrick jako architekt, tłum. U. Franczyk, [w:] Stanley Kubrick w opinii krytyki zagranicznej..., s. 175. Jack „zamarza na śmierć w środku ogrodowego labiryntu (częsty symbol podświadomości), co sugerować może asymilację bohatera z duchem Overlook i samym hotelem”. W. Parrill, Stanley Kubrick, przeł. A. Chajewski, [w:] Stanley Kubrick w opinii krytyki zagranicznej..., s. 90.

38 J. Hani, Symbolika świątyni chrześcijańskiej, przeł. A.Q. Lavique, Kraków 1998, s. 101.

39 Imperfect Symmetries...

40 A. Bienk, Filmsprache, Marburg 2008, s. 130. W ramach uzupełnienia dodajmy, że niebieski w estetyce filmowej uważa się również „za kolor nocy, zimna, demoniczności, śmierci, wspomnienia smutku i melancholii”. S. Marschall, Farbe im Kino, Marburg 2009, s. 61 . 
mnianych fragmentach w odzieniu Danny'ego również można dostrzec tę barwę, ale

[...] tym jednak, co się naprawdę rzuca w oczy, jest jego [chłopca - K.K.] czerwona bluza, groźnie harmonizująca $\mathrm{z}$ wizjami leżących we krwi martwych ciał dziewczynek. Nie ulega wątpliwości, że Kubrick odsłania w ten sposób całą grozę tej „negatywnej transcendencji”, której najważniejszym symbolem jest obraz wylewającej się $\mathrm{z}$ windy krwi ${ }^{41}$.

Danny prawie zawsze ma na sobie ubranie, na którym zestawiony zostaje kolor niebieski i czerwony. Zasada ta zostaje złamana dwukrotnie, przy czym kluczowym jest, że za pierwszym razem w ubraniu chłopca dominuje kolor niebieski, a w kolejnym czerwień. Kubrick zatem w sposób jawny wiąże transcendencję z czymś niebezpiecznym, a wręcz demonicznym. Jack będzie z kolei konsekwentnie ukazywany z barwą słońca, czyli żółtym - symbolizującym „boskie źródło światła”42. Odcienie tego koloru będą obecne w elementach scenograficznych, a także w przedmiotach, jakie towarzyszą głównemu bohaterowi - samochód marki Volkswagen, marynarka, piłka tenisowa, likier, który wylewa na Jacka Delbert Grady, czy sok pomarańczowy przyniesiony przez Wendy na śniadanie. Znamienne, że Kubrick w bardzo sugestywny sposób również żółty powiąże z kolorem demoniczności i niebezpieczeństwa. Hallorann w drodze do hotelu Overlook ujrzy wypadek samochodowy. W niebezpiecznym karambolu znajdzie się przygnieciony przez tira czerwony „Garbus”, czyli identyczny model Volkswagena, jaki posiada rodzina Torranców. Kluczowe jest jednak, że w opisanej scenie żółty kolor samochodu bohaterów zostaje zastąpiony czerwonym.

Wróćmy jednak do kwestii znaczenia samego labiryntu, którego wszelkie wyobrażenia:

są ilustracją podróży człowieka ku śmierci i odrodzeniu - a przez to wyobrażeniem nieskończoności. Labirynt zakłada [...] dwa cele. Dla wędrowca, który zapuszcza się w labirynt, celem jest osiągnięcie centralnej komory, krypty tajemnic, ale gdy już się ją osiągnie, powinien z niej wyjśś i powrócić do świata zewnętrznego, to znaczy na nowo się narodzić. Taka jest treść wszystkich religii zawierających element tajemnicy, i wszystkich sekt uważających wędrówkę w labiryncie za niezbędny proces metamorfoz, z którego wyłania się nowy człowiek $^{43}$.

${ }^{41}$ K. Kozłowski, dz. cyt., s. 57.

42 S. Marschall, dz. cyt., s. 75.

${ }^{43}$ P. Santarcangeli, dz. cyt., s. 179. Santarcangeli wprost też formułuje, że „w ciągu wieków [...] symbol spirali i symbol labiryntu uległy zmianom pod względem formy i treści [...] pozostaną one jednak zawsze w tej samej dziedzinie znaczeniowej - płodności, wieczności, życia tajemnego, podziemnego". P. Santarcangeli, dz. cyt., s. 178. 
W labiryncie znajduje się zatem droga wiodąca do śmierci, a zarazem do przyszłego życia - „poza śmierć"44. Odnosząc się do wszystkich przytoczonych wypowiedzi, można zauważyć, że w przypadku Jacka rzeczywiście w symbolicznym sensie dokonuje się zwycięstwo nad przestrzenią i czasem, w szczególności biorąc pod uwagę refleksję Borgesa dotyczącą kwestii pojmowania wieczności. Jack pragnie w końcu wyzwolić się z więzienia ,jednoczasowości”, a tym samym posiąść wspomniany „atrybut boskości” 45 . Podobną myśl sugerują słowa „unwinding hours”, które znajdują się na tablicy umieszczonej przed salą Gold Room. Przytoczone sformułowanie można przetłumaczyć jako coś w rodzaju „nieustannie rozwijających się godzin”. Skojarzenie z nieograniczoną czasowością same się zatem nasuwają ${ }^{46}$.

Kluczowa wydaje się scena, w której główny bohater, popadając stopniowo $\mathrm{w}$ obłęd, $\mathrm{z}$ szaleństwem $\mathrm{w}$ oczach spogląda na replikę labiryntu znajdującą się w Sali Colorado. Przyglądając się temu ujęciu, trudno oprzeć się wrażeniu, że labirynt jest w przytoczonym fragmencie wyrazem stanu psychicznego głównego bohatera, a wręcz symbolem jego zniewolenia ${ }^{47}$. Zresztą w scenie, w której Jack powtarza dwa razy Danny'emu, że chciałby zostać w hotelu „na zawsze”, pojawia się ten sam utwór muzyczny, jaki można było usłyszeć w momencie, kiedy Wendy chodziła razem z Dannym po labiryncie. Odzwierciedleniem wspomnianego miejsca jest również sam hotel Overlook, sprawiający wrażenie molocha. Żona Jacka sama zresztą dostrzega podobieństwo w scenie, w której Hallorann oprowadza Wendy i Danny'ego po budynku. Zakończenie Lśnienia, nawet odczytywane $\mathrm{w}$ ramach osiągnięcia przez bohatera wieczności, wzbudza jakąś niewytłumaczalną trwogę. Nieprzypadkowe wydaje się, że mężczyzna stojący na fotografii za Jackiem wyraźnie trzyma go za rękę - zagadkowy i niepokojący jest ten gest...

44 Tamże, s. 155.

45 „Labirynt jest także więzieniem, w którym pragnie się, by pozostał ten, kto tam wszedł, z którego nie może wyjść, przynajmniej do chwili swego ewentualnego «odrodzenia»" (tamże, s. 183).

46 Pauline Kael, pisząc dla „The New Yorkera”, wyraziła sugestię, że w Lśnieniu pojawia się idea braku czasowości (What did Pauline Kael think of THE SHINING?, <http://krusch.com/kubrick/Q54b.html>, dostęp: 09.12.2014). Z podobną ideą czasu można się też spotkać w filmie Alaina Resnais Zeszłego roku w Marienbadzie (1961). Zob. K. Kościelski, Orfeusz i Eurydyka w Marienbadzie, „Kwartalnik Filmowy” 2014, nr 86, s. 76-91.

47 „Podwójna natura labiryntu - podróż w jego głąb, eksploracja i równoczesne pragnienie ucieczki - to centralny problem Kubricka, związany z przestrzenią, wyrażający się poprzez poczucie zamknięcia się przestrzeni, klaustrofobię i dążenie do wyzwolenia się" (M. Ciment, dz. cyt., s. 114). Często wskazuje się również na symboliczny charakter przestrzeni w filmach Kubricka, z której ograniczeń bohaterowie starają się wyzwolić. W przypadku Lśnienia dobrze wyraża tę kwestię wprowadzony przez Kubricka motyw labiryntu (zob. G.P. Brunetta, dz. cyt., s. 68). 


\section{Podsumowanie}

Jeżeli losy Edgara Allana Poego, wikingów, Judasza Iskarioty i twoje, czytelniku, są w tajemny sposób tym samym losem - jedynym możliwym losem - historia powszechna jest historią jednego człowieka. [...] Marek Aureliusz głosi podobieństwo, a nie identyczność wielu indywidualnych losów. Dowodzi, że wszelki okres czasu - wiek, rok, jedna noc, niepojęta być może teraźniejszość - w pełni mieści w sobie historię. Owo domniemanie w jego skrajnej postaci łatwo obalić: jeden smak różni się od innego, a dziesięć minut fizycznego bólu przeciwstawia się dziesięciu minutom algebry. W odniesieniu do długich okresów czasu, jak siedemdziesiąt lat życia przyznawanych nam przez Księgę Psalmów, domniemanie to jest prawdopodobne czy też dopuszczalne. Sprowadza się do twierdzenia, iż liczba postrzeżeń, emocji, myśli, ludzkich niedoli jest ograniczona i wyczerpiemy ją przed śmiercią ${ }^{48}$.

Nie tylko w eseju Kolisty czas Borges próbował określić, w jaki sposób pojmuje ludzką egzystencję. Pisarz w utworze Osnowa wprost zauważa, że „los lubi powtórzenia, warianty, symetrie"49. W związku z twórczością Kubricka niejednokrotnie pojawiała się refleksja odnośnie do „powtarzającej się cyklicznie historii, niezmiennie doświadczanej”50 przez filmowe postacie. W Lśnieniu sytuacja, w jakiej znajdą się główni bohaterowie, nie tylko korespondować będzie z losem, który spotkał rodzinę Grady'ego. Kubrick w końcowych scenach buduje też nawiązanie do jednej z mitycznych opowieści. Warto niewątpliwie zauważyć zdeformowaną postawę, jaką przybiera Jack z powodu zranionej nogi, a także nieartykułowane dźwięki, które wydobywają się z ust bohatera, kiedy z siekierą w ręku kluczy po ścieżkach ogrodowego labiryntu. Zachowanie Jacka świadczy oczywiście o jego kompletnym „zezwierzęceniu”, ale podkreśla również pokrewieństwo z mitologiczną postacią Minotaura, na którym

ciąży los [...] istoty, przeznaczonej przez bogów, by była okrutna i równocześnie, by została za to okrucieństwo ukarana. [...] dopełnia się w nim nie tylko los zwierzęcia, które ma zostać złożone w ofierze, lecz także wtargnięcie bestialstwa (sodomii) w człowieka; sodomia, która jako taka powinna być karana śmiercią $[\ldots]^{51}$.

48 J.L. Borges, Historia wieczności, przeł. A. Elbanowski, Warszawa 2006, s. 85-86.

49 Tenże, Osnowa, [w:] Twórca, przeł. Z. Chądzyńska i K. Rodowska-Wiesiołowska, Warszawa 1974, s. 24. Zob. też J.L. Borges, Temat zdrajcy i bohatera, [w:] Opowiadania..., s. $110-114$.

50 R. Lacayo, Semper Fi, [w:] Stanley Kubrick w opinii krytyki zagranicznej..., s. 188. Zob. też G.P. Brunetta, dz. cyt., s. 65, 66 i 70; P. Kletowski, dz. cyt., s. 304-305.

${ }^{51}$ P. Santarcangeli, dz. cyt., s. 10. Autor w dalszej części zauważa: „tam, gdzie labirynt uważa się za drogę śmierci i życia, bardzo często przedstawia się go także słownie lub malarsko, «jako miejsce, w którym ma być zamknięty nieboszczyk»; lub lepiej, gdzie ma zostać zamknięte razem z nim nasze (ludzi żyjących) nieczyste sumienie”. Tamże, s. 183. 
Odnosząc końcowe sekwencje do wspomnianej legendy, można przyjąć, że w tym wariancie Danny jawiłby się jako Tezeusz, a Wendy byłaby odpowiednikiem Ariadny. Labirynt pojmuje się przecież także jako figurę, która „przedstawia ludzką egzystencję - czyli - życie z jego wszelkimi odmianami losu"52.

Postawa Jacka wyraża odwieczny temat ludzkiego pragnienia związanego z osiągnięciem wieczności. Transcendencja w obrazie Kubricka nabiera demonicznego charakteru, stając się powodem definitywnego upadku głównego bohatera. Ze względu na przypisaną naszemu gatunkowi kondycję wciąż podlegamy tym samym - „niezmiennie doświadczanym przez śmiertelników" - fizycznym i duchowym uwarunkowaniom. Powtarzalność ludzkich losów sprowadza się do przemierzonych już niegdyś ścieżek ogrodowego labiryntu. Niezależnie od tego, o jakim czasie byśmy nie mówili.

52 J. Hani, dz. cyt., s. 100. Interesujące są też inne powiązania między Lśnieniem a motywem labiryntu. Dla przykładu przydomek Pazyfae - żony Minosa - w języku angielskim tłumaczony jest jako „wide-shining”. Samo „słowo «labirynt» pochodzi od starogreckiego labrys, które w kulturze wczesnoegejskiej oznacza podwójny topór o przeznaczeniu sakralnym" (M. Lurker, Przestanie symboli $w$ mitach, kulturach i religiach, przeł. R. Wojnakowski, Kraków 1994, s. 179). Miniaturka tej broni znajduje się na biurku Ullmana. 